\title{
SPIRITUAL DIRECTION IN AN AFRICAN CONTEXT: CHALLENGES AND OPPORTUNITIES
}

Direção espiritual em contexto africano: desafios e oportunidades

Jean Luc Enyegue*

\begin{abstract}
An upset spiritual director just ended a retreat with a group of African priests because they could not observe strict silence. Similar situations elsewhere on the continent led a young African student to raise the question of the suitability of sixteenth-century Spiritual Exercises to modern Africans. This essay acknowledges the challenges facing spiritual directors to "accurately" apply the method of the Spiritual Exercises in a diverse and ever-evolving, noisy and busy world. From the concrete experience of this group of priests, it argues for the suitability of the Exercises to the African context based on the adaptability and flexibility inherent in Ignatius' Spiritual Exercise and subsequent directories. The particular crisis between this director and his retreatants, however, also presents a unique opportunity for retreat directors to find creative ways to accommodate retreatants with specific needs, and to communicate the message of the Exercises in a way that is both accessible to and respectful of the African worldview.
\end{abstract}

KEYWORDS: Retreat Director. Diocesan African Context. Blended Retreat. Confession and Narrativity.

RESUMO: Um diretor espiritual chateado simplesmente encerrou um retiro com um grupo de padres africanos porque eles não conseguiam observar estrito silêncio. Situações similares em outros lugares do continente levaram um jovem estudante africano a pôr-se a questão da adequação dos Exercícios Espirituais do século XVI aos africanos contemporâneos. Este texto reconhece os desafios enfrentados pelos diretores espirituais para aplicar "com precisão" o método dos Exercícios Espirituais

* Jesuit Historical Institute in Africa, Nairobi, Kenya. 
em um mundo diversificado, sempre em evolução, barulhento e ocupado. A partir da experiência concreta daquele grupo de sacerdotes, ele defende a pertinência dos Exercícios no contexto africano com base na adaptabilidade e flexibilidade inerentes aos Exercícios Espirituais de Inácio e aos diretórios subsequentes. A crise particular entre aquele diretor e seus retirantes, entretanto, também representa uma oportunidade única para que os diretores de retiros encontrem maneiras criativas de acolher retirantes com necessidades específicas, e de comunicar o material dos Exercícios de uma maneira que seja acessível e respeitosa à visão de mundo africana.

PALAVRAS-CHAVE: Diretor de retiro. Contexto diocesano africano. Retiro misto. Confissão e narratividade.

\section{Introduction}

For the sake of discretion, let's call this director Jean Guibert in this essay. He had established his reputation as a master in giving the Spiritual Exercises of Saint Ignatius of Loyola (1491-1556). Now, in his seventies, Guibert faces a new challenge. A bishop, somewhere in Africa, just invited him to give the Spiritual Exercises to the priests of his diocese. The retreatants were about ninety, part of the intellectual elite of the African country. Yet, they were unfamiliar with the Spiritual Exercises. The priests welcomed the new initiative of their bishop with a certain dose of curiosity. That Guibert was such a renowned Jesuit predisposed them favorably. Guibert was welcomed warmly. His hosts drove him around the region under a weather that seemed cooler than what Guibert, in this first African visit, had expected. He was happy. His African experience could not have a better start, until the first night of the retreat.

"I urge you," Guibert began, "to turn off your mobile phone from this moment on, and to observe strict silence". He quoted the Spiritual Exercises to support his claim. To create a proper environment for the retreat, the second annotation of Ignatius' autographical directory insists on a place where we are not seen, where we cannot speak to anyone; while the third annotation advises to eat only what is necessary (SEBASTIÀ, 2000, p. 19) ${ }^{1}$. The Scripture reading for the meditation reinforced the grace to be asked during this first day of the retreat. Like Jesus at the end or dawn of a busy day, they asked for the grace to withdraw into this deserted place to pray (Luke 5:16; Mark 1:35), in strict silence.

\footnotetext{
${ }^{1}$ Translations of the Directorios are taken from: Miguel Lop Sebastià, trans., Los Directorios de Ejercicios, 1540-1599 (Bilbao: Ediciones Mensajero;Sal Terrae, 2000), 19. However, in his response to Juan de Polanco, Ignatius nuances the latest point related to food by demanding to inquire about what the Exercitant wants to eat, according to his own devotion. The retreatant can further "communicate" what he/she wants for the next meal to the one serving his/her meals (Ibid., 21).
} 
The room, indeed, went quiet; increasingly and worryingly quieter. Father Guibert, it seemed, had achieved his initial goal. The silence in the room, however, was one before the storm. Back in the yard and the corridors of the retreat center, there were blue-lights everywhere, soon followed by shouty conversations and laughter. Then small groups of priests were formed. They greeted each other, hugged, and laughed again. Father Guibert took his rosary and went around the yard to pray, in an attempt to make his presence known with the hope of imposing some order. His stratagem did not work. In fact, some priests went in their rooms, and kept talking.

An angry Guibert showed up for the orientation the next day. He expressed his deep disappointment, the lack of silence. Since the autographical directory recommends the director to "exigir cuenta de los puntos" (SEBASTIÀ, 2000, p. 21), Guibert urged his audience again to observe silence, because without silence, he argued, one cannot properly do the Spiritual Exercises. The retreatants noted the anger, and something condescending in his tone: "Who is this man," they murmured, "to speak to big parish priests, university professors, and priests that way?" During the third orientation, almost nobody was listening to the director anymore. The bishop tried to intervene; but the rupture was irreparable.

A disappointed Guibert, again, followed Ignatius' directory: If the retreatant does not obey the director, "no conviene continuar en darle los ejercisios" Father Guibert interrupted the retreat, believing that he did not fail as spiritual director. How could he, given his credentials? African diocesan priests, he concluded instead, are incapable of properly doing the Spiritual Exercises. They cannot observe strict silence.

Ten years later, one of the priests who attended Guibert's drama replaced the old bishop. He believed the Spiritual Exercises were necessary to improve the spiritual life of his priests. He called another Jesuit, African, newly ordained and with no name recognition, to give the annual retreat to the priests. He warned the new director about the trauma of Guibert's retreat.

How the young Jesuit navigated this situation with the diocesan priests is the focus of this essay. At the time of the bishop's invitation, José García de Castro had not yet published his work on a "Silent God in a Wordy World" in which the Spanish author acknowledges that there was no clear relationship with silence among the first Jesuits (GARCÍA DE CASTRO, 2016, p. 184). More, García de Castro argues, "despite the methodological relevance given to silence in the Spiritual Exercises, it is not an important topic in the Ignatian text" (GARCÍA DE CASTRO, 2016, p. 184).

Aware of Guibert's experience with the priests, similar stories of Jesuit priests in Africa, and following a request to give a presentation for a re-

${ }^{2}$ Directorio 3, Nota 12. 
treat direction course on "Spiritual Direction in the African Context", I am trying to consider a recurrent question: should there be a distinctive way to give a retreat in an African context in the first place? If so, how far can the adaptation of the same and their methods go? If an experienced retreat director like Jean Guibert, and many others, have reached the conclusion that some groups of priests are incapable of silence, and therefore, of doing the Spiritual Exercises, should these priests be left on their own even if they are "apt for religion" 3 ? Is there a way to meet them where they are and still be faithful to the Spiritual Exercises of Saint Ignatius of Loyola? Analyzing Guibert's case and the importance of silence in the Spiritual Exercises and in a "wordy world", the essay argues in favor of flexibility in the adaptation of the Spiritual Exercises and their methods. Different social groups, different cultures, different contexts and different worldviews require methodological adjustments and creativity from the retreat director to facilitate direct communication between God and the ones doing the Spiritual Exercises.

\section{Should there be Spiritual Exercises specific for Africans in the first place?}

On the method, the Second Annotation of the Spiritual Exercises seems to leave little room for adaptation: "The one who explains to another the method and order of meditating or contemplating should narrate accurately the facts of the contemplation or meditation" (DE LOYOLA, 2000, p. 5). According to Santiago Arzubialde, mode and order means 1) exposing faithfully the main points; 2 ) telling the true story, giving the main idea and the ultimate meaning of the ministry it reveals, the story as told in the gospel or the matter to be meditated or contemplated; 3 ) feel the story: affectionately impressed, and admiring the story as it unfolds; 4) showing how the story is illuminated by divine virtue (ARZUBIALDE, 2009, p. 65).

This annotation is also alluded to in the $15^{\text {th }}$ and $16^{\text {th }}$ annotations of the autographical directory. In it, the retreat director, after he had carefully studied the book, has to "read" what is written and as it is written in the book (SEBASTIÀ, 2000, p. 21). The spirit of these annotations was confirmed by the 28th General Congregation (1929) of the Jesuits, when the fathers decreed:

In giving the Exercises, ours should faithfully abide by the method used by Our Holy Father Ignatius; they should therefore become most conversant with both

\footnotetext{
${ }^{3}$ Concerning being "apt to religion" as a precondition to do the Spiritual Exercises, see Polanco's letter to Juan Pelletier, May 30, 1556. The same letter recommends that the Spiritual Exercises be given to married couple who might not qualify for the religious state, but who nevertheless attend church. They can be given the first week, with focus on the "examination of conscience", and something on the "modo de orar" (SEBASTIÀ, 2000, p. 39).
} 
the book of the Exercises and the Directory [...] the Superior General [should] see the preparation of an instruction on the manner of giving the Exercises accommodated to our times, keeping, however, the earlier and venerated Directory of the Exercises intact (PADBERG; O'KEEFE; MCCARTHY, 1994, p. 608)4.

For this essay, "accuracy" does not necessarily exclude adaptation or interpretation. It is not, therefore, synonymous to an originalist interpretation of the text, i.e., abiding "by the method used by Our Holy Father Ignatius". Attempts for an originalist interpretation in the practice of the Spiritual Exercises have their roots in the fact that until late in the $16^{\text {th }}$ century, there were no commentaries on the Spiritual Exercises. The first Jesuits were too close to the source, Ignatius. They were aware of Ignatius' intent and understanding of the Spiritual Exercises and their method. They felt no need to interpret, comment, or illustrate them (SEBASTIÀ, 2000, 15) 5 .

While Ignatius himself, and the first exercitants who received the Spiritual Exercises from him, wrote some "directories" for the practice of the Spiritual Exercises, it was not until the generalate of Everard Mercurian (1573-1580) that an official "Directory" took shape, before it was published under Claudio Aquaviva (1599). At the time, there were no Jesuits left with direct experience to the origins (SEBASTIÀ, 2000, pp. 17-18). The so-called original directory, "autographical", was, nevertheless, a transcript of "oral explanations" given by Ignatius to his retreatants (SEBASTIÂ, 2000, p. 19). It is therefore legitimate to suspect a gap between the oral and the redaction of what was said into written form. The allusion to "explanation" is an indication that Ignatius himself did not see the Spiritual Exercises as a book to be eaten, but read and put into practice. He left room for explanation and interpretation.

In chapter 6 of his De religione Societatis Iesu', - chapters 5, 6 and 7 of which are in defense of the Spiritual Exercises -, Francisco Suárez first admits that the Spiritual Exercises, exactly because they are "spiritual," cannot be strictly reduced to any method since no one can tie the Spirit to a particular method or mode of action. Instead, Suárez admits, it is proper to the Spirit to inflame the heart and the soul as it wishes (SUÁREZ, 2003, p. 125).

Yet, Suárez also sees in the short size of the booklet Ignatius' intent to observe the method, leaving little room for expansive explanation from the director. God, Ignatius believed, was to communicate directly to the

\footnotetext{
${ }^{4}$ General Congregation 28, Decree 30.

${ }^{5}$ Faber, Salmerón, Francisco Villanueva, Domenech are cited by da Câmara to be those whose methods Ignatius approved in a special way. Cf. D 6 (SEBASTIÀ, 2000, p. 43).

${ }^{6}$ This essay uses the Spanish translation of the three chapters of the De Religione, in defense of the Spiritual Exercises. Cf. Francisco Suárez, Los Ejercicios Espirituales de San Ignacio: Una Defensa, trans. Josep Giménez Melià (Bilbao: Mensajero; Sal Terrae, 2003).
} 
retreatant. Despite this intent, "the method of the Spiritual Exercises is to be accommodated to their end: the salvation of souls" (SUÁREZ, 2003, 133). While Ignatius insisted on the form or method of the Spiritual Exercises, he also wanted the directors to take into account the "way of being of the people who are instructed, in such a way that some way is opened to the uneducated and rude and the same matter is distributed to them a little" (SUÁREZ, 2003, 145).

Ignatius' flexibility allows certain adaptations on the method of the Spiritual Exercises. The accurate transplant of an organ by a surgeon is not good enough if the receiving body rejects the new organ. For instance, Ignatius encourages the one giving the retreat to an "unskilled" person to focus on the First Week (Annotation 9). It is no secret that the African context shows disproportionate representation between, on the one hand, the intellectual and religious elite who often do the Exercises, and, on the other hand, the vast majority of Christian poor also in need of them. Unless the priests and religious sisters, or the upper-class well-educated Catholics remain the primary target of the Spiritual Exercises, adaptation is needed to reach the vast majority of unskilled African Catholics.

The same flexibility is observed in the Eighteenth Annotation: The Spiritual Exercises must be adapted to the condition of the one who is to engage in them, to his/her age, education, and talent. Even when offered to "great sinners," Suárez argues, immediate perfection is not to be expected from them (SUÁREZ, 2003, p. 179). The Exercises' ultimate goal is the salvation of the soul. For those who are already in the clerical state, Alfredo Sampaio recalls, there was no doubt in Ignatius' mind that the Spiritual Exercises is meant for their sanctification within their elected state (SAMPAIO, 2004, p. 11-12). From the beginning, Ignatius understood that it was not the same thing to give the Spiritual Exercises to Jesuits, to non-Jesuit religious, "seglares", and to the laity (SUÁREZ, 2003, p. 27). This classification did not follow any order of perfection. It was, instead, an acknowledgment of different states in the Christian vocation, and an admission that the Spiritual Exercises be adapted to each group of people out of respect for their particular state.

\section{Imagining an African Adaptation to Ignatius' Method of the Spiritual Exercises}

A student taking the course on Spiritual Direction, rightly pointed out that any originalism in the application of the method of the Spiritual Exercises in the African context can only be speculative, and even obsolete since Ignatius himself never gave the Spiritual Exercises to an African, and unlikely had Africans in mind as he was writing his booklet. The voice of 
the student speaks to another reality proper to African scholars. There is a well-established critique of the concept of "universality" among African Christians, including some with strong Ignatian background, who argue that all claim to universality is a universalization of a particular (EBOUSSI BOULAGA, 1984). Therefore, applying a method used by Ignatius among sixteenth-century Europeans to $21^{\text {st }}$ century Africans can create certain malaise among those critiques of one-sided universalism.

Yet, one still has to try to make sense of Ignatius' approach in the $21^{\text {st }}$ century Africa. Our common humanity and sharing of certain rationality demands it. Humans everywhere, Ignatius assumed, are capable of receiving Christ's offer of salvation. Catholics worldwide share some universal truths and values. Finally, in the current context of globalization, isolating Africa can simply be synonymous to self-defeat in an ever-evolving world and shifting dynamics in global Christianity (ROBERT, 2000, p. 50-58).

Imagine, from Ignatius's correspondance, how he would have directed a retreat to, let's say, the Negus of Ethiopia. Such an attempt might not be historically accurate (it simply never happened), and yet, it is still Ignatian. To "imagine" is a key feature of Ignatian Spirituality. In fact, discovering the method of the Spiritual Exercises based on correspondence is not unprecedented. The cases of Juan de Polanco, Gonçalves da Câmara, and others who wrote the directories of the Spiritual Exercises are well known. Some of these directories were inspired by Ignatius' correspondance to individual exercitants or directors who sought for advice.

It is by paying attention to Ignatius' approach to the Jesuit mission to Ethiopia that one can gather the knowledge Ignatius had for Africa. From this knowledge, it is possible to "imagine" what would have been his adaptation of the method in an African context. Some might see in this attempt a bridge too far. It can miss the transition from the method applied to someone in a retreat center and the reality of another person in the mission field. This dichotomy exists if only we focus on the method, independently of the substance and the ultimate goal of the Spiritual Exercises.

Concerning the substance, the Spirit is not bound by the rigidity of the method. As for the goal, any dichotomy would fail the test of the ultimate aim of Ignatian Spirituality. The Spiritual Exercises are about the experience of a retreatant, trying to find God in everything by stripping oneself off disordered affections (EE, n. 21). The exercitant is thus led to the salvation of his/her soul. In the process, the person acquires the skills to discern, and, in the routine of his/her life, becomes a contemplative in action. In Jesuit missionary tradition, this adaptability is known as accommodation. It is a process of opening up to the universal while, at the same time, inculturating (ARRUPE, 1978), and domesticating the Christian message (CREARY, 2011). The Spiritual Exercises favorably predispose the Jesuit 
missionary toward the unknown other, in curious lands (MUNGELLO, 1989), as in disputed missions (ŽUPANOV, 1999). While not without perils (PRIETO, 2017), Jesuit adaptability which finds its roots in the Spiritual Exercises also creates conditions for cross-cultural interaction, respect, and accommodation.

Early contacts between Roman Catholics and Ethiopian Christians multiplied from the $12^{\text {th }}$ century (BOUCHAUD, 1952; and MVENG, 1963). Franciscan missionaries arrived in Ethiopia around 1350 (THORNTON, 2001). Ethiopian monks took part in the Council of Florence-Ferrara in 1438, in the context of marriage negotiations between the court of Aragon and Ethiopia (GILL, 1959). A Portuguese expedition led by Diogo Gomes stopped in Benin around 1456-62 (GARRETSON, 1993). They believed that they had found Prester John (of Ethiopia) in the Benin region. After Gomes, Diogo Çao's expedition in 1482 still believed that Benin and Ethiopia were the same (MCALISTER, 2012), until Çao's expedition went further south (CHRISTIAN, 1945). It is during that expedition that King Nzinga a Nkuwu of Kongo was converted in 1491 (THORNTON, 1993a), the birth year of Saint Ignatius. This Kongolese Christianity competed with Ethiopian Christianity (GEBREKIDAN, 2010), and had an impact in the Caribbean and the Americas (THORNTON, 1988).

Ignatius' own sources on Ethiopia were twofold. First, he read Francisco Alvarez's The True Relation of the Lands of Prester John (ÁLVAREZ, 1961). $\mathrm{He}$ is also said to have conversed with an Ethiopian monk in Rome (O'MALLEY, 1969). Interestingly, Ignatius urged the Jesuits he sent to Ethiopia to gain Prester John through the means of "respect, friendship, disputatio (reason), and example of life" $\mathrm{e}^{\prime 7}$. Yet, he also believed that there is no salvation outside the church, which means that the rules to sentire cum ecclesia had to apply. Prester John was to acknowledge the supremacy of the pope, "Vicar of Christ". He urged the Jesuits sent to Ethiopia to focus their pastoral work on the "moderation" of the abuses of the Old Law (Sabbath), and its austerities. They should, instead, encourage exterior feasts, Corpus Christi processions, and promote a strong sacramental spirituality. Masses, but also vespers should be accompanied with choir and organ (which Ignatius kept the Jesuits from doing) ${ }^{8}$.

\section{The Way Forward: Blended Silence, Controlled Noises}

As the young African was directing the retreat to the priests, the liturgies, lauds and vespers were sung and accompanied by the xylophones (Bala-

\footnotetext{
${ }^{7}$ Letters to the Negus and João Nunes Barreto, Patriarch of Ethiopia, July 1554-February 1555.

${ }^{8}$ Ibid.
} 
fons). All the hymns and the psalms were in their African language. As they sang, the priests were moving slowly in a choreography, following the rhythm of the balafons. The experience of singing together created, by itself, a spiritual effervescence among the retreatants. The priests were having a good time being together, celebrating mass together, praying together. They did so while doing the Ignatian Spiritual Exercises.

The young director was invited again the following year. This time, the retreat was taking place in the middle of the FIFA World Cup competition in which five African countries were participating. One African team had even reached the quarter finals of the competition. The game was played during the penultimate day of the third week of the retreat. In the context of most African countries, such a game takes precedence over most activities. In Cameroon, for example, it does not matter whether or not these are priests. Cameroonians just like watching football and want nothing to interfere with it.

How, then, to insert the football game into the retreat program? On the eve of the football game, the director gave the points on the crucifixion for the next day. The room was quiet, as he remembered the bishop's warning concerning Jean Guibert's experience. The retreatants listened to him carefully. At the end, the director announced a change in the program. Stricter silence was to be observed that night than ever before. After all, it was about the passion and death of our good Lord. The priests will have no conversations during and after the meals, including during the dish-washing. They would keep the same silence the next day, including during meals and cleaning. Their time of walk in the afternoon was canceled. With a note of humor, he added, the priests came for the retreat because they wanted to pray. Of all the days of the retreat, this particular day was not a joke.

That night was quiet. So was the day. After the first retreat, they had come to trust the director and to respect him. Why? During his first retreat with the priests, the young Jesuit broke the ice with humor and by a simple acknowledgment:

I know how busy you are in your parishes; you might even have pending burials; and being the only priest in a rural parish, if someone dies, I won't be surprised to have your faithful coming here to interrupt your retreat. Their parent deserves a decent Catholic burial. While Ignatius wanted the retreat to be in absolute silence, I would understand to see some of you using their phone at least for the first couple of days. Just make sure that I don't see you when you use it, and that you do not disturb the neighbor who is praying or trying to rest.

With this introduction, the young Jesuit acknowledged Ignatius' initial intent as applied by Guibert. By imposing strict silence, the European retreat director was right about the importance of silence, especially applied 
to "retiros cerrados" (closed retreats). Even García de Castro admits that "consolation is the experience of silence" (GARCÍA DE CASTRO, 2016, p. 194). Guibert failed, however, to understand diocesan life in Africa, and the life of a parish priest in an African village. He did not listen to the needs of his audience and to his new environment, including the impossibility of total and immediate rupture from parish life. Because the young African Jesuit showed the priests, from the beginning, that he understood them and respected them, they were willing to be directed.

At $3 \mathrm{pm}$, on game day, the director told the priests that he had agreed with the bishop to turn on the TV. Those who wanted could watch the game. Should the African team lose the game, all will continue with the passion. If it wins, they will move on to the Resurrection. The African team lost. They needed little effort to receive the painful and sorrowful grace of the day.

Has the young African director not broken Ignatius' rules on silence? In Directory 4, drawn from Ignatius or Polanco's response to Juan Alfonso de Vitoria in 1555, Vitoria's first annotation reads that "it is not appropriate to exhort anyone to lock themselves up to do the Exercises if they do not have those conditions" (SEBASTIÀ, 2000, p. 29). The one who does not have such conditions should not receive the Exercises either (SEBASTIÀ, 2000, p. 29). Writing again to Felipe Leerno, February 3, 1554, Polanco advises not to lock people up, "but rather that they take a few hours a day for this purpose, because in this way the usefulness of the Spiritual Exercises can be communicated to many until general confession and some way of praying as has been said" (SEBASTIÀ, 2000, p. 38).

Additionally, if the Spiritual Exercises should penetrate all aspects of our lives and missions, the diversity of the same require that the Spiritual Exercises be adapted. From the $32^{\text {nd }}$ General Congregation of the Jesuits:

Inherent in this Ignatian practice of spiritual direction is a deep respect for the Exercitant as he is and for the culture, background, and tradition that have gone into making him what he is. Moreover, the pedagogy of the Spiritual Exercises is a pedagogy of discernment. It teaches a man to discover for himself where God is calling him, as he is, where he is, among his own people (CG 32, D 4, 57) (PADBERG; KILEY, 2009, p. 311).

Moreover, the young African understood who the good director is. According to Brian Grogan,

God is the director; I am a helper, the giver of the retreat (...) When grace enters my heart, I come to see that while I cannot make a success of the retreat, God can and will. My fear then becomes something more like 'holy fear'; a fear that I may get in God's way, that I may be a bad and useless instrument (GROGAN, 1991, p. 179). 
The director, therefore, is "the one who gives the Spiritual Exercises". The first giver was Ignatius himself, and, after him, the first Companions. Ignatius, himself, was directed by God. God was his first director. Ignatius even admitted, to the perils of being suspected of illuminism, that God can communicate directly to the retreatant. Only then did Ignatius direct others. The director should therefore be familiar with God, follow God's guidance, regardless of place and time, in Africa, in Asia, or in Europe or America. Yet, the director needs to be a good listener: a listener of God and a listener of the retreatant and God's work in the retreatant.

In the particular context of this retreat to diocesans, 80 per cent of the diocesan parishes are rural. Priests, most of the year, live alone in villages, with little socialization. Most do not have access to internet, sometimes to phones or even TV. Unlike the Jesuits, the diocesan parish priests do not have a community life. Their community are the parishioners. So, when they come together once a year for their annual retreat, what is the goal, or what should it be? Jean Guibert proposed the grace of silence. He was not wrong. As García Jiménez de Cisneros understood, busy and restless priests, during this annual retreat, were brought to the harbor, "in a secret and quiet place", so that the retreat would help them "to calm the heart and make the seeker ready to enter the greater mysteries of the proposed contemplative path" (TYLER, 2018, p. 258).

Yet, and maybe, lonely priests simply needed, not strict silence as such, but a blended silence i.e., a time of silent prayer combined with opportunities of socialization among brothers and friends with whom they had been in formation together. The hugs and laughter were logical. Imposing silence was deemed to be counter-productive. What they needed was a blended experience of community life, conversations, singing and dancing, sharing meals and stories, and yes, moments of silence. The retreatants had brought ordinary life in what Guibert understood primarily as a closed retreat. What the second director did was to admit this reality. His role, then, was to facilitate an environment of ordinary life in a closed environment with controlled moments of active community life and silent prayer. Maurice Giuliani believes that bringing in the "real" "helps actualize the gospel, illuminate a new depth of the incarnation of the church, and specifies the criteria of judging the movements of the Spirit within us" (GIULIANI, 1992, p. 18).

\section{How to Tell the Story: A Narrative Approach to the Spiritual Exercises}

Further, the second director knew that Africans have a way of communicating. There is not a single reality that constitutes "Africanness". Like 
any culture, being African is "dynamic, forward-moving, and undergoing constant change and transformation" (OROBATOR, 2018, p. 7). God's language is not the same all the time and everywhere. "In times past," says the Letter to the Hebrews, "God spoke in partial and various ways to our ancestors through the prophets" (Heb 1:1). As he/she listens to God's language in the retreatant, the director has to pay attention to the language of his/her own ancestors. This language comes with its biases, prejudices, and insecurities. There is a possibility that Jean Guibert faced the wall of this unfamiliar African language. Centuries of "assumptions" about "africanness" are well established and permeate even the self-understanding of some Africans. Therefore,

to learn about Africa first entails a process of unlearning stereotypes, prejudices, and biases [...] Africa is a million thing: fifty-four countries, one billion people (and counting), and up to three thousand languages are compressed into one vast geo-political entity! By any calculation, that qualifies Africa as complex, if not bewildering (OROBATOR, 2018, p. 6).

The director has to pay attention to the environment of the retreatants, and their ancestral language. To understand the language of Africans, says Birago Diop, we have to listen to the Breath of the ancestors. This ancestral language is sometimes spoken in "things rather than beings," and in the "voices of the dead" who, exactly because they have a voice, "are not dead" (DIOP, 1951, p. 187-189).

Despite the differences, though, African theologians believe that there is a common denominator to Africans' approach to religion and spirituality. Religion is primarily "a way of life," and is "expressed through ritual and worship, myths and narratives, ethics and norms" (OROBATOR, 2018, p. 13). Engelbert Mveng found the best expression of this life-giving African spirituality in the rhythms of its liturgies (MVENG, 1964a), especially that of the xylophones (MVENG, 1972), poetry (MVENG, 1962), art (MVENG, 1964b), paintings, etc. By this process, "he was concerned not just to promote African art and its expression of African thought and identity, but also to see how African theology and symbolism might become a basis for liturgy of the (Roman Catholic) Church" (HACKETT, 1994, p. 303-4).

This spirituality of life is facing new challenges today. According to Laurenti Magesa, the culture of "imposition," which is the way Africans experience the ongoing globalization (MAGESA, 2010, p. 50), might have been what the priests rejected from Guibert's approach. Instead, Magesa provides a definition of the African worldview which sees spirituality primarily as "a way of behaving", not a state of being. This worldview involves relationships with different powers, visible and invisible, and is oriented toward the achievement of "good life" as opposed to "bad life" (MAGESA, 1997, p. 33). From this African context, Dieudonné Mushipu Mbombo argues 
spiritual direction should be a pastoral activity. It is understood primarily in the pastoral context (MBOMBO, 2014, p. 446). The best method for spiritual direction, therefore, is that of lived experience.

Therefore, narrativity is key to communicate in the African context. The narrative approach has the advantage of finding its raison d'être in the Spiritual Exercises and the Autobiography of Ignatius of Loyola. As Africans embrace narrativity, they tend to write biographies and autobiographies. Orobator's Confessions of an Animist is autobiographical. So is Lamin Sanneh's Summoned from the Margins (SANNEH, 2012). Confession, should we recall, is the main grace of the First Week of the Spiritual Exercises, and every confession is autobiographical. It implies self-examination of one's entire life, including places and times, just before making an "election", which is the discerning process that leads to a "choice of a way of life". Ignatius and the first Jesuits understood that to do spiritual direction, to direct a retreat, is sometimes limited to that: an examination (goal of the Spiritual Exercises as stated in the first Annotation), a confession, or a discernment that might lead one to change his/her life.

Sanneh, for example, tells a story of how, before he married Sandra (a European), he had to introduce her to his relatives so that she can be "examined" before being fully accepted and incorporated in her new society (SANNEH, 2012, p. 3). This initiation is common in many African cultures. As he writes his own history and his journey from the margins of an African society to the center of the world, Sanneh has two groups of peoples to remember: the support of people impossible to list and without whom his journey would not have turned out the way it did (SANNEH, 2012, p. 16-17). The second group of people is the tragic story in the section of the book reserved to "acknowledgement" (SANNEH, 2012, p. xv).

The story of Susan told in this book is that of many African women, of broken lives in need of healing and reconciliation, of a spiritual journey that would give them new meaning in life. To direct them toward this light, Sanneh, again, uses his own autobiography as a starting point. Similarly, the Center for Global Christianity and Mission of Boston University has a digital project on African Christian biographies. The goal of the project is to tell the untold history of African church leaders in the long history of Christianity in Africa. Yet, as Dana Robert argues in the introductory chapter of the book, the goal is to find the "meaning of the Christian faith broadened and deepened through studying the lives of Africans". In that sense, she says,

biography is powerful. On a popular level, biography introduces ordinary people to the excitement of history by exploring the loves, hates, struggles, and victories of actual human beings. It names human realities along the journey from birth to death-a life pathway that all people share. Biography illustrates 
how people construct meaning in the midst of social, cultural, and political processes that often seem overwhelming and uncontrollable. When hearing about or reading about the life of someone with whom we identify, our own lives are validated, and we are strengthened for the struggles ahead. In short, through biography people become, to borrow a concept made popular by liberation theology, the 'subject of their own history' (ROBERT, 2018, x).

The African priests attending the retreat belonged to this network of stories, with their own hopes and anxieties. Communicating God's word to them "requires paying attention to ways that God continues to reveal the seed of God's Word in the lives of individuals who, in their own ways fully live the Gospel in the concrete history of Africa" (ILO, 2018, p. 58-59).

\section{Conclusion}

There is, certainly, an African story, an African way of communicating, and, therefore, an African way of directing a retreat. This African way requires, from the director, great dose of self-examination and listening to overcome prejudices, biases, insecurities, and miscommunication which might step in the way of them helping the retreatant to have his/her own experience of God. To do the Spiritual Exercises in an African context is to adopt a language, narrativity, and a method, and the lived experience which narrativity implies. This language, depending of context, can be technical, the language of the initiated, of the proverbs, etc. It can also be the language of the street or the market. A Jesuit in Kinshasa would, for example, be giving the Spiritual Exercises to street children. Another would have to make it meaningful to his rural parishioners, most of whom are unlettered. To be understood, the retreat director should listen to the environment, and tell a story; the story of a concrete human being or human community with God, accessible to his/her audience.

\section{Acronyms}

$\mathrm{CG}=$ General Congregation

$\mathrm{D}=$ Decree (of a General Congregation)

$\mathrm{EE}=$ Spiritual Exercises

\section{References}

ÁLVAREZ, D. F. The Prester John of the Indies: a True Relation of the Lands of the Prester John, Being the Narrative of the Portuguese Embassy to Ethiopia in 1520. Cambridge: Cambridge University Press, 1961. 
ARRUPE, P. On Inculturation. Acta Romana, Roma, v. XVII, fasc. 78, p. 256-281, May 1978.

ARZUBIALDE, S. Ejercicios Espirituales de San Ignacio: Historia y Análisis. Bilbao: Mensajero, 2009.

BOUCHAUD, J. La côte du Cameroun dans l'histoire et la cartographie: Des origines à l'annexion allemande (1884). Paris: Institut Francais d'Afrique Noire, 1952.

CHRISTIAN, J. L. Portuguese India and Its Historical Records. The Hispanic American Historical Review, v. 25, n.1, p. 140-151, Feb. 1945.

CREARY, N. M. Domesticating a Religious Import: the Jesuits and the Inculturation of the Catholic Church in Zimbabwe, 1879-1980. New York: Fordham University Press, 2011.

DE LOYOLA, I. The Spiritual Exercises of St Ignatius of Loyola. New York: Vintage, 2000.

DIOP, B. Souffles. Présence Africaine, Paris, n. 12, p. 187-189, 1951.

EBOUSSI BOULAGA, F. Christianity Without Fetishes: An African Critique and Recapture of Christianity. New York: Maryknoll, 1984.

GARCÍA DE CASTRO, J. Silent God in a Wordy World: Silence in Ignatian Spirituality. Theologica Xaveriana, Bogotá, v. 66, n. 181, p. 177-205, Jun. 2016.

GARRETSON, P. P. A Note on Relations Between Ethiopia and the Kingdom of Aragon in the Fifteenth Century. Rassegna Di Studi Etiopici, Roma, v. 37, p. 37-44, 1993.

GEBREKIDAN, F. N. Ethiopia and Congo: A Tale of Two Medieval Kingdoms. Callaloo, Texas, v. 33, n. 1, p. 223-238, 2010.

GILL, J. The Council of Florence. Cambridge: The University Press, 1959.

GIULIANI, M. La Experiencia de Los Ejercicios Espirituales En La vida. Bilbao: Mensajero; Sal Terrae, 1992.

GROGAN, B. The One Who Gives the Exercises. In: SHELDRAKE, Philip (Ed.). The Way of Ignatius of Loyola: Contemporary Approaches to the Spiritual Exercises. Saint Louis, MO: Institute of Jesuit Sources, 1991. p. 179-190.

HACKETT, R. I. J. Art and Religion in Africa: Some Observations and Reflections. Journal of Religion in Africa, Leiden, v. 24, p. 294-308, Nov. 1994.

ILO, C. S. Stories My Grannies Never Told Me: Memory and Orality in the Narrative of African Christian History. In: Robert, D. L. African Christian Biography. Pietermaritzburg: Cluster Publications, 2018. p. 42-62.

MAGESA, L. African Religion: The Moral Traditions of Abundant Life. Nairobi: Paulines, 1997.

MAGESA, L. Moral and Ethical Issues in African Christianity. In: MAGESA, L. African Theology Come of Age. Nairobi: Paulines, 2010. p. 45-56.

MBOMBO, D. M. Le Récit Du Pèlerin de Saint Ignace de Loyola et Son Rôle Formatif Dans l'Accompagnement Spirituel: L'Apport Des Sciences Humaines Par l'Herméneutique 
Classique et La Psychologie Culturelle Dans La Lecture Pastorale d'un Tel Récit. Fribourg: Academic Press, 2014.

MCALISTER, E. Listening for Geographies: Music as Sonic Compass Pointing Toward African and Christian Diasporic Horizons in the Caribbean. Black Music Research Journal, Champaign, v. 32, n. 2, p. 25-50, Fall 2012.

MUNGELLO, D. E. Curious Land: Jesuit Accommodation and the Origins of Sinology. Hawaii: University of Hawaii Press, 1989.

MVENG, E. Si Quelqu'un...: chemin de croix. Tours: Mame, 1962.

MVENG, E. Histoire Du Cameroun. Paris: Presence Africaine, 1963.

MVENG, E. L'art d'Afrique Noire: Liturgie Cosmique et Langage Religieux. Paris: Mame, 1964a.

MVENG, E. L'Art Africain: II - Le Rythme. Présence Africaine, Paris, n. 52, p. 104-124, 1964b.

MVENG, E. Balafon. Yaoundé: Éditions CLE, 1972.

O'MALLEY, J. W. Fulfillment of the Christian Golden Age under Pope Julius II: Text of a Discourse of Giles of Viterbo, 1507. Traditio, Cambridge, v. 25, p. 265-338, 1969.

OROBATOR, A. E. Religion and Faith in Africa: Confessions of an Animist. New York: Orbis Books, 2018.

PADBERG, J. W.; KILEY, P. Jesuit Life \& mission Today: the Decrees of the 31st-35th General Congregations of the Society of Jesus. St. Louis, MO.: Institute of Jesuit Sources, 2009.

PADBERG, J. W.; O'KEEFE, M. D.; MCCARTHY, J. L. For Matters of Greater Moment: The First Thirthy Jesuit General Congregations. Saint Louis, MO: The Institute of Jesuit Sources, 1994.

PRIETO, A. I. The Perils of Accommodation: Jesuit Missionary Strategies in the Early Modern World. Journal of Jesuit Studies, Boston, v. 4, n. 3, p. 395-414, Jun. 2017.

ROBERT, D. L. Introduction: Why African Christian Biography?. In: ROBERT, D. L. African Christian Biography. Pietermaritzburg: Cluster Publications, 2018. p. viii-xx.

ROBERT, D. L. Shifting Southward: Global Christianity since 1945. International Bulletin of Missionary Research, Princeton, v. 24, n. 2, p. 50-58, Apr. 2000.

SAMPAIO, A. Los Tiempos de Elección En Los Directorios de Ejercicios. Bilbao: Ediciones Mensajero, 2004. (Colección Manresa)

SANNEH, L. O. Summoned from the Margin: Homecoming of an African. Grand Rapids, MI.: Eerdmans, 2012.

SEBASTIÀ, L. M. Los Directorios de Ejercicios, 1540-1599. Bilbao: Ediciones Mensajero; Sal Terrae, 2000.

SUÁREZ, F. Los Ejercicios Espirituales de San Ignacio: una defensa. Bilbao: Mensajero; Sal Terrae, 2003.

THORNTON, J. K. On the Trail of Voodoo: African Christianity in Africa and the Americas. The Americas, Oceanside, v. 44, n. 3, p. 261-278, Jan. 1988. 
THORNTON, J. K. 'I Am the Subject of the King of Congo': African Political Ideology and the Haitian Revolution. Journal of World History, Ogden, v. 4, n. 2, p. 181-214, Fall 1993.

THORNTON, J. K. The Origins and Early History of the Kingdom of Kongo, c. 1350-1550. The International Journal of African Historical Studies, Boston, v. 34, n. 1, p. 89-120, 2001.

TYLER, P. Oración Mental, Mindfulness, and Mental Prayer: The Training of the Heart in the Iberian School of Abbot García de Cisneros of Montserrat and St. Teresa of Avila. Buddhist-Christian Studies, Honolulu, v. 38, n. 1, p. 253-266, 2018.

ŽUPANOV, I. G. Disputed Mission: Jesuit Experiments and Brahmanical Knowledge in Seventeenth-Century India. New Delhi: Oxford University Press, 1999.

Article submitted on March 18, 2021 and accepted on July 2, 2021.

Jean Luc Enyegue SJ, Ph.D Director Jesuit Historical Institute in Africa (JHIA). Senior Lecturer at Hekima University College. Orcid.org/0000-0002-5140-7877. enyegue@jesuits.net

Address: Joseph Kangether, Off Ngong Road 21215 Nairobi, Kenya 